\title{
Perubahan Warna Kulit Buah Tiga Varietas Jeruk Keprok dengan Perlakuan Degreening dan Suhu Penyimpanan
}

\author{
Skin Color Changes on Three Varieties of Tangerines with Degreening and Storage Temperature \\ Treatments
}

\author{
Hanifah Muthmainnah ${ }^{1}$, Roedhy Poerwanto ${ }^{1^{*}}$ dan Darda Efendi ${ }^{1}$
}

Diterima 15 November 2013/Disetujui 14 Januari 2014

\begin{abstract}
Color is the main quality that determines the level of demand for citrus. Consumer prefers orange citrus, where as green citrus have high productivity in Indonesia. It causes local citrus can not compete with imported citrus. One way that can make local citrus compete with import citrus is by improving of colour quality through degreening. This research was conducted to study the effect of degreening and storage temperature on color changes of tangerine peel. Research was conducted from June until July 2013 at the Laboratory of Center for Tropical Horticulture Studies, IPB. This research used a randomized complete factorial design group 2 factors with 3 replications. The first factor is degreening temperature $\left(18{ }^{\circ} \mathrm{C}\right.$ and room temperature), second factor is storage temperature $\left(18^{\circ} \mathrm{C}\right.$ and room temperature). The results showed that interaction of degreening and storage temperature significantly affected skin coloration. Degreening treatment $18{ }^{\circ} \mathrm{C}$ and room temperature storage on all three varieties of tangerines have the highest Citrus Colour Index (CCI) value at 15 HSP. The higher value of Citrus Colour Index, the higher orange skin coloration produced.
\end{abstract}

Key words : degreening temperature, orange, storage temperature, value of Citrus Color Index.

\begin{abstract}
ABSTRAK
Warna merupakan kualitas utama yang menentukan tingkat permintaan konsumen terhadap buah jeruk. Konsumen lebih menyukai jeruk berwarna jingga, padahal di Indonesia jeruk yang tinggi produktivitasnya adalah jeruk berwarna hijau. Hal ini menyebabkan jeruk lokal kalah bersaing dengan jeruk impor. Salah satu cara supaya jeruk lokal dapat bersaing dengan jeruk impor adalah dengan melakukan degreening. Penelitian ini dilakukan untuk mempelajari efek degreening dan suhu penyimpanan terhadap perubahan warna kulit jeruk keprok. Penelitian dilaksanakan dari bulan Juni hingga Juli 2013 di Laboratorium Pusat Kajian Hortikultura Tropika, IPB. Penelitian ini menggunakan Rancangan Kelompok Lengkap Teracak (RKLT) Faktorial dengan dua faktor dan tiga ulangan. Faktor pertama adalah suhu degreening $\left(18{ }^{\circ} \mathrm{C}\right.$ dan suhu ruang), faktor kedua adalah suhu simpan $\left(18{ }^{\circ} \mathrm{C}\right.$ dan suhu ruang $)$. Hasil penelitian menunjukkan interaksi suhu degreening dan suhu simpan nyata pada perubahan warna. Perlakuan degreening suhu $18{ }^{\circ} \mathrm{C}$ dan penyimpanan suhu ruang pada ketiga varietas jeruk keprok memiliki nilai Citrus Colour Index (CCI) tertinggi dibandingkan perlakuan lainnya pada 15 HSP. Semakin tinggi nilai CCI, maka warna kulit jeruk yang dihasilkan semakin jingga.
\end{abstract}

Kata kunci: jingga, nilai Citrus Color Index, suhu degreening, suhu penyimpanan.

\section{PENDAHULUAN}

Jeruk mempunyai nilai ekonomi dan mengandung gizi yang cukup tinggi. Jeruk dapat dikonsumsi dalam bentuk segar maupun olahan. Permintaan konsumen terhadap buah jeruk semakin meningkat disebabkan oleh peningkatan jumlah penduduk, pendapatan

${ }^{1}$ Departemen Agronomi dan Hortikultura, Fakultas Pertanian, Institut Pertanian Bogor

Telp. \& Faks. 62-251-8629353*e-mail untuk korespondensi: roedhy8@yahoo.co.id 
dan kesadaran masyarakat terhadap nilai gizi. Data BPS (2012) produksi jeruk lokal mencapai 1611 juta ton. Deptan (2013) pada bulan Juli 2013 volume impor jeruk mencapai 2230 ton sedangkan ekspor jeruk hanya 73 ton. Standar konsumsi buah yang ditetapkan Food and Agriculture Organization (FAO) sebesar 65.75 kg per kapita per tahun, jika 10\% dari jumlah standar FAO tersebut adalah buah jeruk maka dengan jumlah penduduk 237 juta jiwa (BPS, 2010) akan dibutuhkan 1422 juta ton per tahun (Balitjestro, 2010). Hal ini menunjukkan seharusnya produksi jeruk nasional dapat memenuhi kebutuhan konsumsi jeruk dalam negeri. Di Indonesia jeruk yang tinggi produktivitasnya ialah jeruk berwarna hijau. Warna jeruk yang tetap hijau disebabkan kandungan pigmen klorofil yang tinggi, dan perombakan klorofil berjalan lambat. Warna hijau pada jeruk merupakan hal yang tidak dikehendaki konsumen karena mengurangi daya tarik konsumen. Hal ini disebabkan oleh anggapan masyarakat bahwa jeruk berwarna hijau mempunyai citarasa yang kurang baik dan memberi kesan bahwa jeruk belum matang.

Warna jeruk merupakan salah satu kualitas utama yang terdiri atas akumulasi karotenoid dan derivatif $\mathrm{C}_{30}$ apocarotenoids. Pembentukan warna jingga pada kulit jeruk disebabkan oleh dua zat warna, yaitu $\beta$-citraurin dan criptoxanthin. $\beta$-citraurin membuat warna kulit jeruk menjadi kemerahan, sedangkan criptoxanthin membuat warna kulit jeruk menjadi kuning. Degreening pada suhu ruang 28-29 ${ }^{\circ} \mathrm{C}$ zat warna yang terbentuk hanya criptoxanthin sehingga seringkali jeruk yang dihasilkan berwarna kuning. Degreening pada suhu rendah $18-20{ }^{\circ} \mathrm{C}$ menyebabkan $\beta$-citraurin dan criptoxanthin terbentuk secara bersamaan sehingga warna jingga kemerahan dapat dihasilkan (Stewart and Wheaton, 1971).

Riyanti (2005) menyatakan bahwa semakin kuning atau jingga warna kulit jeruk, maka permintaan semakin meningkat. Hal ini dibuktikan oleh banyaknya konsumen yang lebih memilih mengkonsumsi jeruk impor karena memiliki penampilan yang lebih menarik yakni berkulit jingga. Para produsen atau distributor jeruk perlu mengubah warna jeruk yang akan dipasarkan menjadi jingga untuk memenuhi permintaan konsumen, salah satu caranya dengan melakukan degreening pada jeruk dengan menggunakan etilen/ethepon, sehingga warna hijau berubah menjadi jingga.
Penyimpanan suhu rendah dapat menghambat kerusakan fisiologis, memperlambat transpirasi dan respirasi, mengurangi kehilangan air, serta menghambat aktivitas mikroorganisme pengganggu sehingga mutu buah sampai ke tangan konsumen masih tetap terjaga dengan baik (Safaryani et al., 2007). Penyimpanan suhu rendah juga dapat memperpanjang mutu fisik (warna dan penampilan/kesegaran, tekstur dan citarasa) dan nilai gizi. Penelitian ini bertujuan untuk membuktikan pengaruh suhu degreening dan suhu penyimpanan terhadap perubahan warna kulit tiga varietas jeruk keprok.

\section{BAHAN DAN METODE}

Penelitian ini dilaksanakan di Laboratorium Pusat Kajian Hortikultura IPB. Penelitian ini dilaksanakan dari bulan Juni sampai dengan bulan Juli 2013. Bahan yang digunakan pada penelitian ini adalah tiga varietas jeruk keprok (Chokun, Fremont, Batu 55), larutan etephon konsentrasi $120 \mathrm{ppm}$, indikator pp, larutan $\mathrm{NaOH} 0.1 \mathrm{~N}$, dan aquades. Alat yang digunakan pada penelitian ini adalah lemari pendingin, colour reader, $\mathrm{pH}$ meter, hand refractometer, hand penetrometer, timbangan analitik, buret, erlenmeyer, labu takar, gelas ukur, pipet volume, pipet tetes, orange juicer, dan pisau.

Penelitian ini mengunakan Rancangan Kelompok Lengkap Teracak (RKLT) Faktorial 2 faktor, yaitu: suhu degreening (suhu $18{ }^{\circ} \mathrm{C}$ dan suhu ruang) dan suhu simpan (suhu $18{ }^{\circ} \mathrm{C}$ dan suhu ruang). Terdapat 12 perlakuan yang diamati, setiap perlakuan diulang sebanyak 3 kali, sehingga terdapat 36 satuan percobaan. Setiap perlakuan diamati 35-40 jeruk dengan 3 jeruk sampel pengamatan warna. Data yang diperoleh diuji menggunakan uji $\mathrm{F}$ (ANOVA) taraf 5\% dan data skoring warna diuji menggunakan uji Friedman kemudian dilanjutkan dengan uji lanjut Duncan Multiple Range Test (DMRT) pada taraf 5\%.

Ketiga varietas jeruk yang digunakan dalam penelitian ini dipanen dari perkebunan jeruk di daerah Tapos, Ciawi, Bogor. Grading dilakukan setelah panen, buah jeruk dipilih yang memiliki ukuran sama dan warna seragam. Jeruk yang terpilih kemudian dicuci, setelah itu dikeringkan dengan tissue. Jeruk yang telah dicuci kemudian dimasukkan ke dalam keranjang, setelah itu dilakukan proses 
degreening. Degreening dilakukan pada suhu ruang dengan konsentrasi $120 \mathrm{ppm}$. Jeruk disemprot satu per satu dengan larutan etephon secara merata, didiamkan beberapa menit. Jeruk yang telah disemprot larutan ethephon kemudian disimpan sebagian pada suhu $18{ }^{\circ} \mathrm{C}$ $\pm 1{ }^{\circ} \mathrm{C}$ dan sebagian pada suhu ruang $28{ }^{\circ} \mathrm{C} \pm 1$ ${ }^{0} \mathrm{C}$ selama $15 \mathrm{jam}$. Jeruk perlakuan degreening suhu $18{ }^{\circ} \mathrm{C}$ sebagian disimpan pada suhu $18{ }^{\circ} \mathrm{C}$ dan sebagian disimpan pada suhu ruang, jeruk perlakuan degreening suhu ruang sebagian disimpan pada suhu $18{ }^{\circ} \mathrm{C}$ dan sebagian disimpan pada suhu ruang. Penyimpanan dilakukan selama 30 hari. Pengamatan selama penyimpanan dilakukan setiap hari dan seminggu sekali. Pengamatan setiap hari, meliputi: nilai Citrus Color Index (CCI), skoring warna, susut bobot dan masa simpan. Pengamatan seminggu sekali, meliputi: kekerasan buah, Padatan Terlarut Total (PTT), Asam Tertitrasi Total (ATT), rasio PTT/ATT (Brix: Acid Ratio) dan pH.

Perubahan warna kulit jeruk diamati setiap hari menggunakan Color Reader selama 30 HSP (Hari Setelah Perlakuan). Menurut Cuesta et al. (1981), warna kulit jeruk atau Citrus Color Index (CCI) didapatkan dengan rumus $=\frac{1000 . \mathrm{a}}{\mathrm{L} \cdot \mathrm{b}}$, dengan $\mathrm{L}$ (Luminosity) $=$ kecerahan, $a=$ perubahan warna hijau ke merah, $b=$ perubahan warna biru ke kuning. Nilai $\mathrm{CCI}<=-5$ (hijau gelap), $-5<\mathrm{CCI}<=0$ (hijau), $0<\mathrm{CCI}<=3$ (hijau kekuningan), $3<$ $\mathrm{CCI}<=5$ (kuning kehijauan), $5<\mathrm{CCI}<=7$ (jingga kekuningan), $7<\mathrm{CCI}<=10$ (jingga), $\mathrm{CCI}>10$ (jingga gelap). Perubahan warna kulit pada ketiga varietas jeruk keprok diamati pada tiga titik yang mulai beubah warna, yaitu: ujung buah, ekuator, dan pangkal buah.

\section{HASIL DAN PEMBAHASAN}

Rekapitulasi hasil analisis sidik ragam seluruh peubah pada Chokun disajikan pada Tabel 1. Suhu degreening berpengaruh nyata hanya pada susut bobot dan $\mathrm{pH}$. Suhu simpan tidak berpengaruh nyata pada semua peubah. Interaksi antara suhu degreening dan suhu simpan nyata hanya pada PTT.

Rekapitulasi hasil analisis sidik ragam seluruh peubah pada Fremont disajikan pada Tabel 2. Suhu degreening berpengaruh nyata pada warna ekuator, warna pangkal buah, dan susut bobot. Suhu simpan berpengaruh nyata pada warna ekuator, warna pangkal buah, susut bobot, PTT dan $\mathrm{pH}$. Interaksi antara suhu degreening dan suhu simpan nyata pada semua peubah yang diamati kecuali warna ujung buah, kekerasan buah, dan ATT.

Rekapitulasi hasil analisis sidik ragam seluruh peubah pada Batu 55 disajikan pada Tabel 3. Suhu degreening berpengaruh nyata hanya pada warna ujung buah dan $\mathrm{pH}$. Suhu simpan berpengaruh nyata pada warna ekuator, susut bobot, dan $\mathrm{pH}$. Interaksi antara suhu degreening dan suhu simpan nyata hanya pada warna ujung buah dan susut bobot.

Tabel 1. Rekapitulasi hasil analisis sidik ragam semua peubah pada Chokun

\begin{tabular}{|c|c|c|c|c|}
\hline Peubah & $\mathrm{D}$ & $\mathrm{S}$ & $\mathrm{DXS}$ & $\mathrm{KK}(\%)$ \\
\hline $\begin{array}{l}\text { Warna Ujung } \\
\text { Buah }\end{array}$ & tn & tn & tn & 5.46 \\
\hline Warna Ekuator & tn & tn & tn & 10.11 \\
\hline $\begin{array}{l}\text { Warna Pangkal } \\
\text { Buah }\end{array}$ & tn & tn & tn & 10.11 \\
\hline Susut Bobot (\%) & $*$ & tn & tn & 5.61 \\
\hline $\begin{array}{l}\text { Kekerasan Buah } \\
\left(\mathrm{kg} \mathrm{detik}^{-1}\right)\end{array}$ & tn & tn & tn & 39.30 \\
\hline PTT $\left({ }^{\circ}\right.$ Brix $)$ & tn & tn & $* *$ & 5.75 \\
\hline $\operatorname{ATT}(\%)$ & tn & tn & $\operatorname{tn}$ & 31.66 \\
\hline $\mathrm{pH}$ & $* *$ & tn & tn & 3.18 \\
\hline
\end{tabular}

Keterangan: $\mathrm{tn}=$ tidak berbeda nyata, $*=$ berbeda nyata pada taraf $5 \%, * *=$ berbeda nyata pada taraf $1 \%, \mathrm{D}=$ Suhu degreening, $\mathrm{S}=$ Suhu simpan, $\mathrm{PTT}=$ Padatan terlarut total, ATT $=$ Asam tertitrasi total

Tabel 2. Rekapitulasi hasil analisis sidik ragam semua peubah pada Fremont

\begin{tabular}{|c|c|c|c|c|}
\hline Peubah & $\mathrm{D}$ & $\mathrm{S}$ & $\mathrm{DXS}$ & KK (\%) \\
\hline $\begin{array}{l}\text { Warna Ujung } \\
\text { Buah }\end{array}$ & tn & tn & $\operatorname{tn}$ & 19.88 \\
\hline Warna Ekuator & $* *$ & $* *$ & $* *$ & 7.79 \\
\hline $\begin{array}{l}\text { Warna Pangkal } \\
\text { Buah }\end{array}$ & $* *$ & $* *$ & $* *$ & 10.49 \\
\hline Susut Bobot (\%) & $*$ & $* *$ & $* *$ & 3.24 \\
\hline $\begin{array}{l}\text { Kekerasan Buah } \\
\left(\mathrm{kg} \mathrm{detik}^{-1}\right)\end{array}$ & tn & tn & $\operatorname{tn}$ & 25.32 \\
\hline PTT $\left({ }^{\circ}\right.$ Brix $)$ & tn & $* *$ & $* *$ & 4.54 \\
\hline $\operatorname{ATT}(\%)$ & tn & tn & tn & 7.58 \\
\hline $\mathrm{pH}$ & tn & $* *$ & $*$ & 7.74 \\
\hline $\begin{array}{r}\text { erangan: } \mathrm{tn}=\text { tid } \\
\text { pada } \\
\text { taraf } 1 \\
\text { simpar } \\
\text { Asam }\end{array}$ & ber & $n$ & $\begin{array}{l}\text { a, } *=1 \\
\text { perbed } \\
\text { green } \\
\text { terlart }\end{array}$ & $\begin{array}{l}\text { beda nyata } \\
\text { yyata pada } \\
\text { S }=\text { Suhu } \\
\text { otal, ATT }\end{array}$ \\
\hline
\end{tabular}


Tabel 3. Rekapitulasi hasil analisis sidik ragam semua peubah pada Batu 55

\begin{tabular}{lcccc}
\hline \multicolumn{1}{c}{ Peubah } & D & S & D X S & $\begin{array}{l}\text { KK } \\
(\%)\end{array}$ \\
\hline $\begin{array}{l}\text { Warna Ujung } \\
\text { Buah }\end{array}$ & $*$ & tn & $* *$ & 6.51 \\
$\begin{array}{l}\text { Warna Ekuator } \\
\text { Warna Pangkal }\end{array}$ & tn & $*$ & tn & 7.48 \\
$\begin{array}{l}\text { Buah } \\
\text { Susut Bobot }(\%)\end{array}$ & tn & $* *$ & $*$ & 10.29 \\
$\begin{array}{l}\text { Kekerasan Buah } \\
\left.\text { (kg detik }{ }^{-1}\right)\end{array}$ & tn & tn & tn & 50.97 \\
PTT $\left({ }^{\circ}\right.$ Brix) & tn & tn & tn & 9.25 \\
ATT $(\%)$ & tn & tn & tn & 9.59 \\
pH & $*$ & $* *$ & tn & 1.89 \\
\hline
\end{tabular}

Keterangan: $\mathrm{tn}=$ tidak berbeda nyata, $*=$ berbeda nyata pada taraf $5 \%, * *=$ berbeda nyata pada taraf $1 \%, \mathrm{D}=$ Suhu Degreening, $\mathrm{S}=\mathrm{Suhu}$ simpan, $\mathrm{PTT}=$ Padatan terlarut total, ATT= Asam tertitrasi total

\section{Perubahan Warna Kulit}

\section{Warna Ujung Buah}

Gambar 1 menunjukkan nilai CCI pada ujung buah. Perlakuan degreening suhu $18{ }^{\circ} \mathrm{C}$ dan penyimpanan suhu ruang pada ketiga varietas jeruk keprok memiliki nilai CCI yang paling tinggi dibandingkan dengan perlakuan lainnya pada 15 HSP. Pada Chokun semua perlakuan berubah menjadi warna jingga pada 20 HSP. Pada Chokun perlakuan penyimpanan suhu ruang menunjukkan perubahan warna menjadi jingga lebih cepat dibandingkan dengan penyimpanan suhu $18{ }^{\circ} \mathrm{C}$. Pada Fremont perlakuan degreening dan penyimpanan suhu $18{ }^{\circ} \mathrm{C}$ berubah warna menjadi jingga pada 25 HSP.

Pada Fremont perlakuan degreening suhu $18{ }^{\circ} \mathrm{C}$ dan penyimpanan suhu ruang berubah warna menjadi jingga pada 15 HSP. Pada Fremont perlakuan degreening dan penyimpanan suhu ruang berubah warna menjadi jingga pada 20 HSP. Pada Fremont perlakuan degreening suhu ruang dan penyimpanan suhu $18{ }^{\circ} \mathrm{C}$ berubah warna menjadi jingga pada $20 \mathrm{HSP}$. Pada Fremont perlakuan penyimpanan suhu ruang menunjukkan perubahan warna menjadi jingga lebih cepat dibandingkan dengan penyimpanan suhu $18{ }^{\circ} \mathrm{C}$.

Pada Batu 55 perlakuan degreening dan penyimpanan suhu $18{ }^{0} \mathrm{C}$ berubah warna menjadi jingga pada 10 HSP. Pada Batu 55 perlakuan degreening suhu $18{ }^{\circ} \mathrm{C}$ dan penyimpanan suhu ruang berubah warna menjadi jingga pada 5 HSP. Pada Batu 55 perlakuan degreening dan penyimpanan suhu ruang berubah warna menjadi jingga pada 15 HSP. Pada Batu 55 perlakuan degreening suhu ruang dan penyimpanan suhu $18{ }^{\circ} \mathrm{C}$ berubah warna menjadi jingga pada $20 \mathrm{HSP}$. Pada Batu 55 perlakuan penyimpanan suhu ruang menunjukkan perubahan warna menjadi jingga lebih cepat dibandingkan dengan penyimpanan suhu $18^{\circ} \mathrm{C}$.
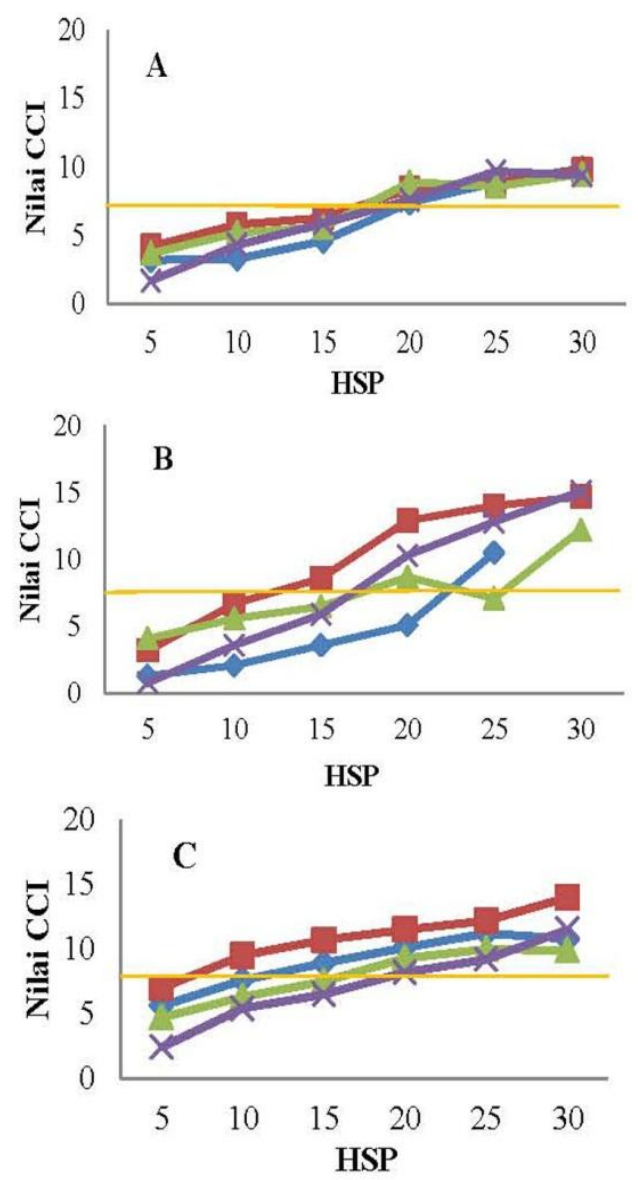

Gambar 1. Nilai CCI pada ujung buah. A) Chokun, B) Fremont, C) Batu 55 perlakuan [degreening dan penyimpanan suhu $18{ }^{\circ} \mathrm{C}(\diamond)$, degreening suhu $18{ }^{0} \mathrm{C}$ dan penyimpanan suhu ruang ( $\square$ ), degreening dan penyim-panan suhu ruang $(\Delta)$, degreening suhu ruang dan penyimpanan suhu $18{ }^{\circ} \mathrm{C}(\mathrm{X})$, dan (-) standar jingga. 


\section{Warna Ekuator}

Gambar 2 menunjukkan nilai CCI pada ekuator. Perlakuan degreening suhu $18{ }^{\circ} \mathrm{C}$ dan penyimpanan suhu ruang pada ketiga varietas jeruk keprok memiliki nilai CCI yang paling tinggi dibandingkan dengan perlakuan lainnya pada 15 HSP. Pada Chokun semua perlakuan berubah warna menjadi jingga pada 20 HSP. Pada Chokun penyimpanan suhu ruang menunjukkan perubahan warna menjadi jingga lebih cepat dibandingkan dengan penyimpanan suhu $18{ }^{\circ} \mathrm{C}$. Pada Fremont perlakuan degreening dan penyimpanan suhu $18{ }^{\circ} \mathrm{C}$ berubah warna menjadi jingga pada 20 HSP. Pada Fremont penyimpanan suhu ruang berubah warna menjadi jingga pada 15 HSP. Pada Fremont perlakuan degreening suhu ruang dan penyimpanan suhu $18{ }^{0} \mathrm{C}$ berubah warna menjadi jingga pada $20 \mathrm{HSP}$. Pada Fremont penyimpanan suhu ruang menunjukkan perubahan warna menjadi jingga lebih cepat dibandingkan dengan penyimpanan suhu 18 ${ }^{0} \mathrm{C}$. Pada Batu 55 penyimpanan suhu $18{ }^{0} \mathrm{C}$ berubah warna menjadi jingga pada 10 HSP. Pada Batu 55 penyimpanan suhu ruang berubah warna menjadi jingga pada 20 HSP. Pada Batu 55 penyimpanan suhu ruang menunjukkan perubahan warna menjadi jingga lebih cepat dibandingkan dengan penyimpanan suhu $18^{\circ} \mathrm{C}$.
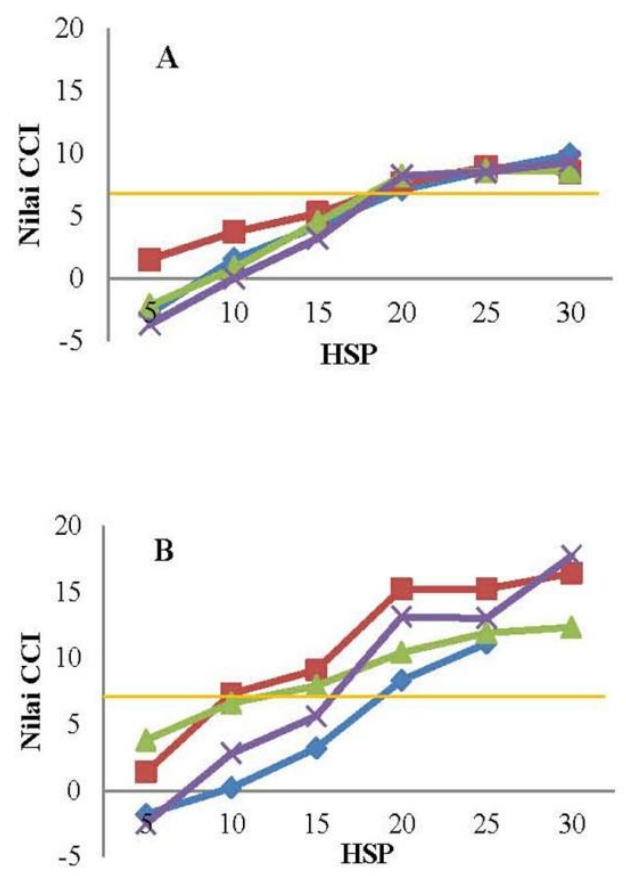

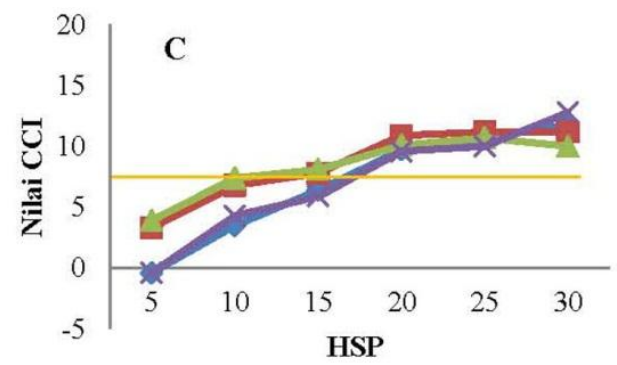

Gambar 2. Nilai CCI pada ujung buah. A) Chokun, B) Fremont, C) Batu 55 perlakuan [degreening dan penyimpanan suhu $18{ }^{\circ} \mathrm{C}(\diamond)$, degreening suhu $18{ }^{\circ} \mathrm{C}$ dan penyimpanan suhu ruang $(\square)$, degreening dan penyimpanan suhu ruang $(\Delta)$, degreening suhu ruang dan penyimpanan suhu $18^{\circ} \mathrm{C}(\mathrm{X})$, dan (-) standar jingga.

\section{Warna Pangkal Buah}

Gambar 3 menunjukkan nilai CCI pada ujung tangkai. Perlakuan degreening suhu 18 ${ }^{0} \mathrm{C}$ dan penyimpanan suhu ruang pada ketiga varietas memiliki nilai CCI yang lebih tinggi dibandingkan dengan perlakuan lainnya pada 10 HSP. Pada Chokun semua perlakuan berubah warna menjadi jingga pada 20 HSP. Pada Chokun perlakuan penyimpanan suhu ruang lebih cepat perubahan warnanya menjadi jingga dibandingkan dengan penyimpanan suhu $18{ }^{\circ} \mathrm{C}$.

Pada Fremont perlakuan degreening dan penyimpanan suhu $18{ }^{0} \mathrm{C}$ berubah warna menjadi jingga pada 20 HSP. Pada Fremont perlakuan degreening suhu $18{ }^{\circ} \mathrm{C}$ dan penyimpanan suhu ruang berubah warna menjadi jingga pada 10 HSP. Pada Fremont perlakuan degreening dan penyimpanan suhu ruang berubah warna menjadi jingga pada $15 \mathrm{HSP}$. Pada Fremont perlakuan degreening suhu ruang dan penyimpanan suhu $18{ }^{\circ} \mathrm{C}$ berubah warna menjadi jingga pada 20 HSP. Pada Fremont perlakuan penyimpanan suhu ruang lebih cepat perubahan warnanya menjadi jingga dibandingkan dengan penyimpanan suhu $18^{\circ} \mathrm{C}$.

Pada Batu 55 perlakuan degreening dan penyimpanan suhu $18{ }^{\circ} \mathrm{C}$ berubah warna menjadi jingga pada 15 HSP. Pada Batu 55 perlakuan degreening suhu $18{ }^{\circ} \mathrm{C}$ dan penyimpanan suhu ruang berubah warna menjadi jingga pada 10 HSP. Pada Batu 55 perlakuan degreening dan penyimpanan suhu ruang berubah warna menjadi jingga pada $10 \mathrm{HSP}$. Pada Batu 55 perlakuan degreening suhu 
ruang dan penyimpanan suhu $18{ }^{\circ} \mathrm{C}$ berubah warna menjadi jingga pada 15 HSP. Pada Batu 55 perlakuan penyimpanan suhu ruang lebih cepat perubahan warnanya menjadi jingga dibandingkan dengan penyimpanan suhu $18{ }^{\circ} \mathrm{C}$.
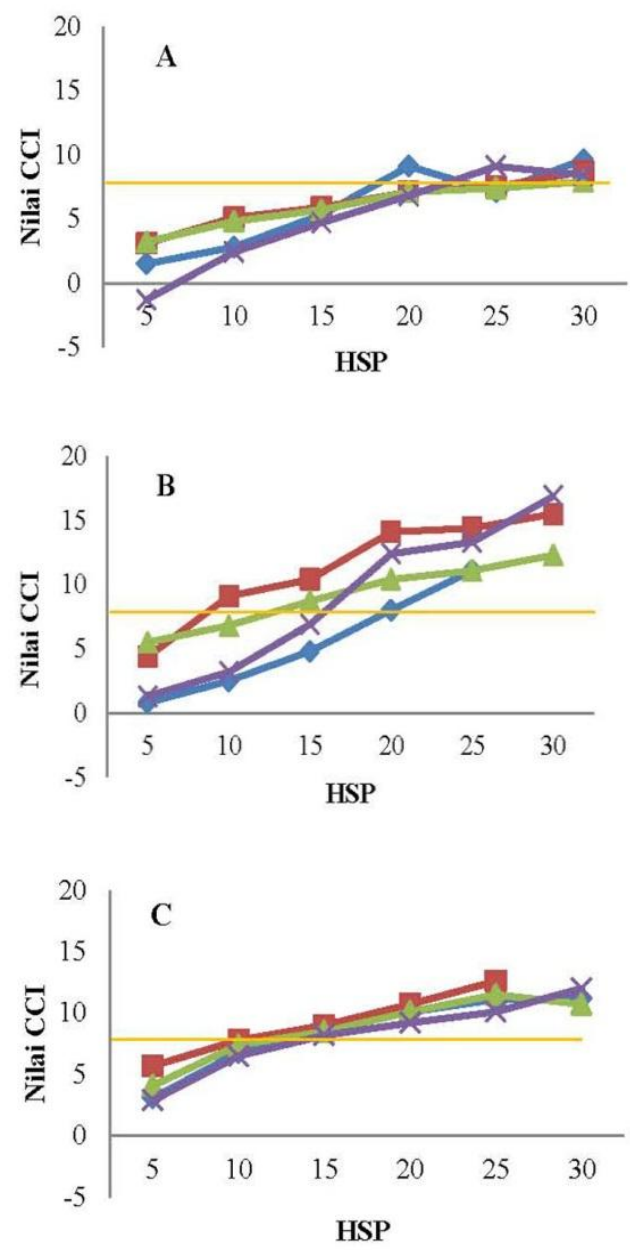

Gambar 3. Nilai CCI pada ujung buah. A) Chokun, B) Fremont, C) Batu 55 perlakuan [degreening dan penyimpanan suhu $18{ }^{\circ} \mathrm{C}(\diamond)$, degreening suhu $18{ }^{\circ} \mathrm{C}$ dan penyimpanan suhu ruang ( $\square$ ), degreening dan penyimpanan suhu ruang $(\Delta)$, degreening suhu ruang dan penyimpanan suhu $18{ }^{\circ} \mathrm{C}(\mathrm{X})$, dan $(-)$ standar jingga.

\section{Warna Rataan Ujung, Ekuator dan Pangkal Buah Jeruk}

Gambar 4 menunjukkan nilai CCI dari rataan ujung, ekuator dan pangkal buah jeruk. Pada Chokun semua perlakuan berubah warna menjadi jingga pada 20 HSP. Pada Chokun perlakuan penyimpanan suhu ruang lebih cepat perubahan warnanya menjadi jingga dibandingkan dengan penyimpanan suhu 18 ${ }^{0} \mathrm{C}$. Pada Fremont perlakuan degreening dan penyimpanan suhu $18{ }^{0} \mathrm{C}$ berubah warna menjadi jingga pada $20 \mathrm{HSP}$. Pada Fremont perlakuan degreening suhu $18{ }^{\circ} \mathrm{C}$ dan penyimpanan suhu ruang berubah warna menjadi jingga pada 15 HSP. Pada Fremont perlakuan degreening dan penyimpanan suhu ruang berubah warna menjadi jingga pada 15 HSP.
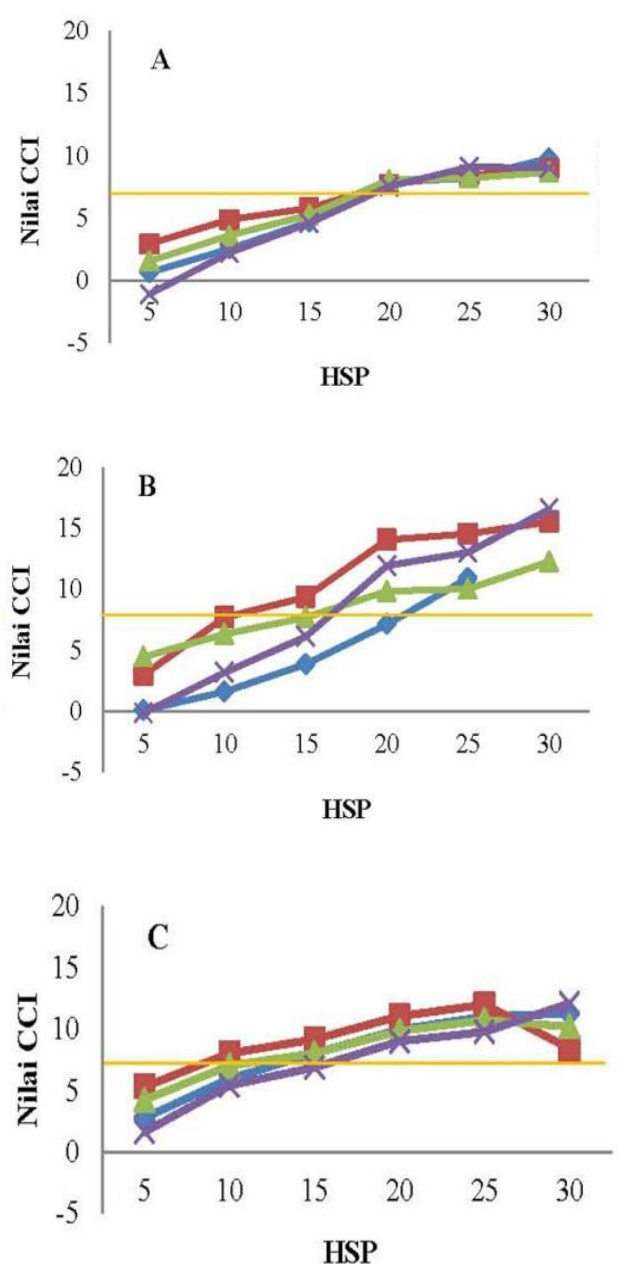

Gambar 4. Nilai CCI pada ujung buah. A) Chokun, B) Fremont, C) Batu 55 perlakuan [degreening dan penyimpanan suhu $18{ }^{\circ} \mathrm{C}(\diamond)$, degreening suhu $18{ }^{\circ} \mathrm{C}$ dan penyimpanan suhu ruang ( $\square$ ), degreening dan penyimpanan suhu ruang $(\Delta)$, degreening suhu ruang dan penyimpanan suhu $18{ }^{\circ} \mathrm{C}(\mathrm{X})$, dan (-) standar jingga. 
Pada Fremont perlakuan degreening suhu ruang dan penyimpanan suhu $18{ }^{\circ} \mathrm{C}$ berubah warna menjadi jingga pada 20 HSP. Pada Fremont perlakuan penyimpanan suhu ruang lebih cepat perubahan warnanya menjadi jingga dibandingkan dengan penyimpanan suhu $18{ }^{\circ} \mathrm{C}$. Pada Batu 55 perlakuan degreening dan penyimpanan suhu $18{ }^{\circ} \mathrm{C}$ berubah warna menjadi jingga pada 15 HSP. Pada Batu 55 perlakuan degreening suhu 18 ${ }^{0} \mathrm{C}$ dan penyimpanan suhu ruang berubah warna menjadi jingga pada 10 HSP. Pada Batu 55 perlakuan degreening dan penyimpanan suhu ruang berubah menjadi jingga pada 10 HSP. Pada Batu 55 perlakuan degreening suhu ruang dan penyimpanan suhu $18{ }^{\circ} \mathrm{C}$ berubah warna menjadi jingga pada $15 \mathrm{HSP}$. Pada Batu 55 perlakuan penyimpanan suhu ruang lebih cepat perubahan warnanya menjadi jingga dibandingkan dengan penyimpanan suhu $18^{\circ} \mathrm{C}$.

\section{Skor Warna Kulit Ketiga Varietas Jeruk Keprok}

Perubahan warna kulit dilihat dari pengamatan skor warna kulit, semakin jingga warna kulit semakin tinggi skornya (Tabel 4). Pengamatan warna CCI menggunakan color reader pada ketiga titik yang diamati memiliki nilai yang berbeda dengan pengamatan warna menggunakan skoring. Hal ini disebabkan pada pengamatan warna CCI menggunakan color reader warna yang diamati adalah warna yang telah berubah menjadi jingga, sedangkan pengamatan warna menggunakan skoring warna diamati secara keseluruhan.

Pada Chokun perlakuan penyimpanan suhu $18{ }^{\circ} \mathrm{C}$ masing-masing menunjukkan skor 4 (30 HSP), berwarna jingga kekuningan. Pada Chokun perlakuan degreening suhu $18{ }^{\circ} \mathrm{C}$ dan penyimpanan suhu ruang menunjukkan skor 3 (30 HSP), berwarna kuning kehijauan. Pada Chokun perlakuan degreening suhu ruang dan penyimpanan suhu ruang menunjukkan skor 0.0 (30 HSP), hal ini disebabkan pada perlakuan ini hanya memiliki satu sampel berwarna kuning (30 HSP), hal ini disebabkan pada perlakuan ini hanya memiliki satu sampel berwarna kuning kehijauan, sedangkan kedua sampel lainnya telah membusuk.

Pada Fremont perlakuan penyimpanan suhu ruang masing-masing menunjukkan skor 6.0 (30 HSP), berwarna jingga. Pada Fremon perlakuan degreening suhu ruang dan pe- nyimpanan suhu $18{ }^{\circ} \mathrm{C}$ menunjukkan skor 6.0 (30 HSP), berwarna jingga. Pada Fremont perlakuan degreening suhu $18{ }^{\circ} \mathrm{C}$ dan penyimpanan suhu $18{ }^{\circ} \mathrm{C}$ pada $30 \mathrm{HSP}$ ketiga sampelnya membusuk, pada 25 HSP menunjukkan skor 0.8 karena hanya memiliki satu sampel yang berwarna kuning kehijauan. Pada Batu 55 perlakuan degreening suhu ruang masingmasing menunjukkan skor 5 (30 HSP), berwarna jingga.

Pada Batu 55 perlakuan degreening suhu $18{ }^{\circ} \mathrm{C}$ dan penyimpanan suhu $18{ }^{\circ} \mathrm{C}$ menunjukkan skor 3.0 (30 HSP), hal ini disebabkan pada perlakuan ini hanya memiliki dua sampel berwarna jingga, sedangkan satu sampel lainnya telah membusuk. Pada Batu 55 perlakuan degreening suhu $18{ }^{\circ} \mathrm{C}$ dan penyimpanan suhu ruang pada 30 HSP ketiga sampelnya telah membusuk, pada 25 HSP kedua sampel menunjukkan skor 5 , berwarna jingga.

\section{Persentase Susut Bobot selama Masa Penyimpanan 25 HSP}

Pengaruh suhu degreening dan suhu simpan terhadap persentase susut bobot buah jeruk disajikan pada Tabel 5. Jeruk yang penyimpanan suhu $18{ }^{\circ} \mathrm{C}$ menunjukkan persentase susut bobot yang lebih rendah dibandingkan dengan jeruk penyimpanan pada suhu ruang. Hal ini disebabkan jeruk penyimpanan suhu $18{ }^{\circ} \mathrm{C}$ lebih dapat mempertahankan bobot buah serta mengalami transpirasi dan respirasi yang dibandingkan dengan penyimpanan suhu ruang. Pada Chokun persentase susut bobot tertinggi terdapat pada perlakuan degreening suhu $18{ }^{\circ} \mathrm{C}$ dan penyimpanan suhu ruang, sedangkan persentase susut bobot terendah terdapat pada perlakuan degreening suhu ruang dan penyimpanan suhu $18{ }^{\circ} \mathrm{C}$. Pada Fremont persentase susut bobot tertinggi terdapat pada perlakuan degreening dan penyimpanan suhu ruang, sedangkan persentase susut bobot terendah terdapat pada perlakuan degreening suhu ruang dan penyimpanan suhu $18{ }^{\circ} \mathrm{C}$. Pada Batu 55 persentase susut bobot tertinggi terdapat pada pada perlakuan degreening dan penyimpanan suhu ruang, sedangkan persentase susut bobot terendah terdapat pada perlakuan degreening suhu ruang dan penyimpanan suhu $18{ }^{\circ} \mathrm{C}$. 
Tabel 4. Skor warna kulit buah jeruk dari semua kombinasi perlakuan

\begin{tabular}{|c|c|c|c|c|c|c|c|c|}
\hline \multirow{2}{*}{ Perlakuan } & \multicolumn{2}{|c|}{$5 \mathrm{HSP}$} & \multicolumn{2}{|c|}{15 HSP } & \multicolumn{2}{|c|}{25 HSP } & \multicolumn{2}{|c|}{30 HSP } \\
\hline & Skor & $\mathrm{Pt}$ & Skor & $\mathrm{Pt}$ & Skor & $\mathrm{Pt}$ & Skor & $\mathrm{Pt}$ \\
\hline \multicolumn{9}{|l|}{ Chokun } \\
\hline $18^{\circ} \mathrm{C}, 18^{\circ} \mathrm{C}$ & 2.0 & $5.0 \mathrm{~b}$ & 3.0 & 7.5 & 3.0 & $8.5 \mathrm{a}$ & 4.0 & 9.5 \\
\hline $18^{\circ} \mathrm{C}$, ruang & 3.0 & $11.0 \mathrm{a}$ & 3.0 & 7.5 & 3.0 & $8.5 \mathrm{a}$ & 3.0 & 5.0 \\
\hline ruang, ruang & 3.0 & $9.0 \mathrm{ab}$ & 3.3 & 7.5 & 0.0 & $4.5 b$ & 0.0 & 6.0 \\
\hline ruang, $18{ }^{\circ} \mathrm{C}$ & 2.0 & $5.0 \mathrm{~b}$ & 3.0 & 7.5 & 3.0 & $8.5 \mathrm{a}$ & 4.0 & 9.5 \\
\hline \multicolumn{9}{|l|}{ Fremont } \\
\hline $18{ }^{\circ} \mathrm{C}, 18{ }^{\circ} \mathrm{C}$ & 1.3 & $5.0 \mathrm{~b}$ & 2.6 & $4.0 \mathrm{~b}$ & 0.8 & $4.0 \mathrm{~b}$ & - & - \\
\hline $18^{\circ} \mathrm{C}$, ruang & 3.0 & $11.5 \mathrm{a}$ & 5.9 & $11.0 \mathrm{a}$ & 6.0 & $10.0 \mathrm{a}$ & 6.0 & 8.5 \\
\hline ruang, ruang & 2.0 & $7.0 \mathrm{ab}$ & 4.9 & $9.0 \mathrm{ab}$ & 5.3 & $8.0 \mathrm{ab}$ & 6.0 & 8.5 \\
\hline ruang, $18^{\circ} \mathrm{C}$ & 1.8 & $6.5 \mathrm{ab}$ & 3.1 & $9.0 \mathrm{~b}$ & 6.0 & $8.0 \mathrm{ab}$ & 6.0 & 8.5 \\
\hline \multicolumn{9}{|l|}{ Batu 55} \\
\hline $18^{\circ} \mathrm{C}, 18{ }^{\circ} \mathrm{C}$ & 2.3 & $6.5 \mathrm{ab}$ & 4.4 & 10.0 & 3.0 & 5.0 & 3.0 & 6.5 \\
\hline $18{ }^{\circ} \mathrm{C}$, ruang & 3.0 & $10.5 \mathrm{a}$ & 3.1 & 6.0 & 5.0 & 9.5 & - & - \\
\hline ruang, ruang & 2.8 & $8.5 \mathrm{ab}$ & 3.9 & 8.0 & 5.0 & 9.5 & 5.0 & 10.0 \\
\hline ruang, $18{ }^{\circ} \mathrm{C}$ & 2.0 & $4.5 b$ & 3.1 & 6.0 & 3.0 & 6.0 & 5.0 & 10.0 \\
\hline
\end{tabular}

Tabel 5. Persentase susut bobot selama penyimpanan 25 HSP

\begin{tabular}{|c|c|c|c|c|c|}
\hline \multirow{2}{*}{ Kombinasi } & \multicolumn{5}{|c|}{ Susut Bobot (\%) } \\
\hline & 5 HSP & $10 \mathrm{HSP}$ & 15 HSP & $20 \mathrm{HSP}$ & $25 \mathrm{HSP}$ \\
\hline \multicolumn{6}{|l|}{ Chokun } \\
\hline $18{ }^{\circ} \mathrm{C}, 18{ }^{\circ} \mathrm{C}$ & 6.5 & $12.6 \mathrm{a}$ & $18.6 \mathrm{ab}$ & $24.5 \mathrm{ab}$ & 30.6 \\
\hline $18^{\circ} \mathrm{C}$, ruang & 6.9 & $12.7 \mathrm{a}$ & $19.4 \mathrm{a}$ & $25.5 \mathrm{a}$ & 32.4 \\
\hline ruang, ruang & 7.3 & $12.7 \mathrm{a}$ & $18.7 \mathrm{ab}$ & $24.1 \mathrm{ab}$ & 29.2 \\
\hline ruang, $18{ }^{\circ} \mathrm{C}$ & 5.1 & $8.9 \mathrm{~b}$ & $14.9 \mathrm{~b}$ & $21.3 \mathrm{~b}$ & 27.9 \\
\hline \multicolumn{6}{|l|}{ Fremont } \\
\hline $18^{\circ} \mathrm{C}, 18^{\circ} \mathrm{C}$ & $6.5 b$ & $12.7 \mathrm{ab}$ & $20.0 \mathrm{ab}$ & $26.9 \mathrm{a}$ & $33.6 \mathrm{ab}$ \\
\hline $18^{\circ} \mathrm{C}$, ruang & 7.4ab & $13.2 \mathrm{ab}$ & $19.6 \mathrm{ab}$ & $25.3 \mathrm{ab}$ & $31.5 b$ \\
\hline ruang, ruang & $10.3 \mathrm{a}$ & $16.6 \mathrm{a}$ & $22.7 \mathrm{a}$ & $29.1 \mathrm{a}$ & $36.9 \mathrm{a}$ \\
\hline ruang, $18{ }^{\circ} \mathrm{C}$ & $4.6 \mathrm{~b}$ & $9.1 \mathrm{~b}$ & $13.4 \mathrm{~b}$ & $18.5 \mathrm{~b}$ & $23.6 \mathrm{c}$ \\
\hline \multicolumn{6}{|l|}{ Batu 55} \\
\hline $18{ }^{\circ} \mathrm{C}, 18{ }^{\circ} \mathrm{C}$ & $4.4 \mathrm{c}$ & $8.4 \mathrm{c}$ & $13.4 \mathrm{bc}$ & $20.3 b c$ & $26.3 b c$ \\
\hline $18^{\circ} \mathrm{C}$, ruang & $6.7 \mathrm{~b}$ & $12.1 \mathrm{~b}$ & $17.6 \mathrm{~b}$ & $23.1 \mathrm{ab}$ & $29.2 \mathrm{ab}$ \\
\hline ruang, ruang & $8.6 \mathrm{a}$ & $16.2 \mathrm{a}$ & $22.5 \mathrm{a}$ & $28.1 \mathrm{a}$ & $34.2 \mathrm{a}$ \\
\hline ruang, $18{ }^{\circ} \mathrm{C}$ & $3.6 \mathrm{c}$ & $8.5 \mathrm{c}$ & $12.6 \mathrm{c}$ & $17.3 \mathrm{c}$ & $22.3 \mathrm{c}$ \\
\hline
\end{tabular}

Keterangan: a Angka-angka yang diikuti huruf sama pada kolom sama tidak berbeda pada taraf uji DMRT 5\% 


\section{Kekerasan Buah dan Analisis Kimiawi}

Kekerasan buah dan analisis kimiawi diamati selama seminggu sekali. Tabel 6 menunjukkan kekerasan buah dan analisis kimiawi pada penyimpanan 2 MSP (Minggu Setelah Perlakuan).

Tabel 6. Kekerasan Buah dan Analisis Kimiawi

\begin{tabular}{|c|c|c|c|c|c|}
\hline Perlakuan & $\begin{array}{c}\text { Kekerasan Buah (kg } \\
\left.\text { detik }^{-1}\right)\end{array}$ & $\operatorname{ATT}(\%)$ & PTT $\left({ }^{\circ}\right.$ Brix $)$ & $\begin{array}{c}\text { Rasio } \\
\text { PTT/ATT }\end{array}$ & $\mathrm{pH}$ \\
\hline \multicolumn{6}{|l|}{ Chokun } \\
\hline $18{ }^{\circ} \mathrm{C}, 18{ }^{\circ} \mathrm{C}$ & $0.91 \mathrm{a}$ & 0.47 & 11.77 & 25.11 & $4.07 \mathrm{~b}$ \\
\hline $18^{\circ} \mathrm{C}$, ruang & $0.56 \mathrm{~b}$ & 0.46 & 11.83 & 25.65 & $5.07 \mathrm{a}$ \\
\hline ruang, ruang & $0.76 \mathrm{ab}$ & 0.53 & 12.27 & 23.21 & $4.99 \mathrm{a}$ \\
\hline ruang, $18{ }^{\circ} \mathrm{C}$ & $0.87 \mathrm{ab}$ & 0.47 & 11.97 & 25.32 & $4.87 \mathrm{a}$ \\
\hline \multicolumn{6}{|l|}{ Fremont } \\
\hline $18{ }^{\circ} \mathrm{C}, 18{ }^{0} \mathrm{C}$ & $1.41 \mathrm{a}$ & 0.50 & 10.37 & 20.80 & 4.48 \\
\hline $18^{\circ} \mathrm{C}$, ruang & $0.87 b$ & 0.70 & 11.40 & 16.29 & 5.01 \\
\hline ruang, ruang & $0.85 b$ & 0.70 & 10.13 & 14.43 & 4.99 \\
\hline ruang, $18{ }^{\circ} \mathrm{C}$ & $1.06 \mathrm{~b}$ & 0.69 & 10.27 & 14.93 & 4.98 \\
\hline \multicolumn{6}{|l|}{ Batu 55} \\
\hline $18^{\circ} \mathrm{C}, 18^{\circ} \mathrm{C}$ & 0.89 & 0.47 & 9.33 & 19.79 & $4.68 \mathrm{~b}$ \\
\hline $18^{\circ} \mathrm{C}$, ruang & 0.69 & 0.41 & 9.97 & 24.15 & $5.13 a$ \\
\hline ruang,ruang & 0.79 & 0.49 & 10.17 & 20.82 & $5.21 \mathrm{a}$ \\
\hline ruang, $18{ }^{\circ} \mathrm{C}$ & 0.74 & 0.40 & 9.27 & 23.25 & $4.62 \mathrm{~b}$ \\
\hline
\end{tabular}

Keterangan: ${ }^{a}$ Angka-angka yang diikuti huruf sama pada kolom sama tidak berbeda pada taraf uji 5\% (uji selang berganda Duncan), PTT= Padatan terlarut total, ATT $=$ Asam tertitrasi total.

\section{Masa Simpan Buah}

Mutu jeruk mengalami kemunduran selama penyimpanan 30 HSP. Mutu simpan buah sangat erat kaitannya dengan proses respirasi dan transpirasi. Hal ini disebabkan susut pascapanen, seperti susut fisik yang diukur dengan bobot, susut kualitas karena perubahan wujud (penampilan), cita rasa, warna atau tekstur yang menyebabkan bahan pangan kurang disukai konsumen, dan susut nilai gizi yang berpengaruh terhadap kualitas buah. Penyimpanan suhu rendah dapat mempertahankan kualitas buah, karena mutu simpan buah akan bertahan lama jika laju respirasi rendah dan transpirasi dapat dicegah dengan cara meningkatkan kelembaban relatif dan menurunkan suhu udara. Utama et al. (2011) melaporkan penggunaan suhu dingin $(12 \pm 1.5$ $\left.{ }^{0} \mathrm{C}\right)$ mampu mengendalikan laju metabolisme dan memperpanjang masa simpan buah manga arumanis. Hal serupa disampaikan Julianti et al. (2013) komposisi perpaduan gas yang terbaik untuk mempertahankan mutu rambutan binjai adalah $4-6 \% \mathrm{O}_{2}, 2-4 \% \mathrm{CO}_{2}$ pada suhu $10{ }^{\circ} \mathrm{C}$. Penyimpanan suhu ruang menunjukkan adanya penurunan kualitas pada buah jeruk hal ini disebabkan oleh transpirasi yang berlebihan karena adanya perbedaan kadar air antara bahan dengan lingkungan tempat penyimpanan. Transpirasi menyebabkan penampilan buah menjadi kurang menarik, susut bobot, keriput, dan kehilangan kesegaran yang akan mengakibatkan penurunan mutu komoditi tersebut (Pantastico, 1973). Penyimpanan suhu ruang juga terdapat cendawan yang menyerang buah jeruk. Golan (2001) menyatakan bahwa keunggulan suhu rendah adalah menurunkan aktivitas enzim-enzim respirasi dengan enzim lain pada jaringan tumbuhan tingkat tinggi, bakteri, dan cendawan. Cendawan yang terdapat pada penelitian ini adalah antraknosa (Colletotrichum gloeosporioides), busuk alternaria (Alternaria citri) dan Phytophthora brown rot (Phytophthora sp.).

Buah jeruk yang digunakan untuk sampel pengamatan warna beberapa diantaranya membusuk. Jumlah buah busuk selama penyimpanan 18 HSP sampai 30 HSP sebanyak 12 buah. Pada Chokun perlakuan degreening dan penyimpanan suhu ruang sebanyak 2 buah sampel membusuk masing-masing pada 18 HSP dan 23 HSP. Pada Fremont perlakuan 
degreening dan penyimpanan suhu $18{ }^{0} \mathrm{C}$ sebanyak 3 buah sampel membusuk pada 23 HSP. Pada Fremont perlakuan degreening suhu $18{ }^{\circ} \mathrm{C}$ dan penyimpanan suhu ruang sebanyak 1 buah sampel membusuk pada 28 HSP. Pada Fremont perlakuan degreening dan penyimpanan suhu ruang sebanyak 1 sampel membusuk 23 HSP. Pada Fremont perlakuan degreening suhu ruang dan penyimpanan suhu $18{ }^{\circ} \mathrm{C}$ sebanyak 1 sampel membusuk pada 29 HSP. Pada Batu 55 perlakuan degreening dan penyimpanan suhu $18{ }^{\circ} \mathrm{C}$ sebanyak 1 buah sampel membusuk pada 28 HSP. Pada Batu 55 perlakuan degreening suhu $18{ }^{\circ} \mathrm{C}$ dan penyimpanan suhu ruang sebanyak 3 buah sampel yang membusuk dengan 1 sampel membusuk pada 26 HSP dan 2 sampel membusuk pada 30 HSP. Masa simpan terlama dimiliki oleh varietas Chokun, semakin banyak buah yang busuk maka semakin rendah masa simpannya dan sebaliknya.

\section{KESIMPULAN}

Perlakuan degreening suhu $18{ }^{\circ} \mathrm{C}$ dan penyimpanan suhu ruang pada ketiga varietas menunjukkan perubahan warna menjadi jingga yang lebih cepat dibandingkan dengan perlakuan lainnya. Pada Chokun interaksi antara suhu degreening dan suhu simpan nyata hanya pada PTT. Pada Fremont interaksi antara suhu degreening dan suhu simpan nyata pada semua peubah yang diamati kecuali warna ujung buah, kekerasan buah, dan ATT. Pada Batu 55 Interaksi antara suhu degreening dan suhu simpan nyata hanya pada warna ujung buah dan susut bobot.

\section{SARAN}

Penelitian menggunakan ethephon sebaiknya dengan konsentrasi diantara $2-5 \mathrm{ml}$ $\mathrm{I}^{-1}$ air atau 500-1000 ppm. Degreening sebaiknya dilakukan selama 2-3 hari. Konsentrasi dan lama waktu degreening tersebut disarankan karena ethephon pada konsentrasi tersebut menghasilkan etilen yang lebih tinggi sehingga lebih cepat menghasilkan warna jingga pada jeruk. Hal ini akan menyebabkan perubahan warna yang dihasilkan lebih baik dan dalam waktu yang lebih singkat.

\section{DAFTAR PUSTAKA}

[Balitjestro] Badan Penelitian Tanaman Jeruk dan Buah Subtropika. 2008. Trend Jeruk Impor dan Posisi Indonesia sebagai Produsen Jeruk Dunia. http//balitjestro.litbang.deptan.go.id. [7 November 2013].

[BPS] Badan Pusat Statistik. 2012. Produksi Buah-buahan di Indonesia 1995-2012. http//www.bps.go.id. [7 November 2013].

Cuesta, M.J., J. Cuquerella, J.M. Javaga. 1981. Determination of Color Index for Citrus Fruit Degreening. Proceeding International Society Citriculture Vol 2: $750-753$.

[Deptan] Departemen Pertanian. 2013. Buletin Bulanan Indikator Makro Sektor Pertanian (Oktober 2013). http//pusdatin. deptan.go.id. [7 November 2013].

Dixon, W.J., F.J. Massey. 1991. Pengantar Analisis Statistik. Edisi Ke-4. Samiyoyono S.K., penerjemah. Soejoeti Z., editor. UGM Pr. Yogyakarta.

Golan, R.B. 2001. Postharvest Disease of Fruit and Vegetables Development and Control. Elsevier Science B.V. Amsterdam.

Gomez, K.A., A.A. Gomez. 2007. Prosedur Statistik untuk Penelitian Pertanian. Edisi Ke-2. Penerjemah E. Sjamsuddin, J.S. Baharsjah, penerjemah. UI Pr. Jakarta.

Julianti, E. Ridwansyah, E. Yusraini, I. Suhaidi. 2013. Pengaruh penyimpanan dengan atmosfir terkendali terhadap mutu buah rambutan varietas Binjai. J. Hort. Indonesia. 4(2): 95-98.

Mitra, S.K. 1997. Postharvest Physiology and Storage of Tropical and Subtropical Fruits. CABI Publishing. London.

Pantastisco, R.B. 1973. Fisiologi Pascapanen (penanganan dan pemanfaatan buahbuahan dan sayur-sayuran tropika dan subtropika). UGM Pr. Yogyakarta. 
Riyanti. 2005. Faktor-faktor yang mempengaruhi permintaan konsumen terhadap buah jeruk. Skripsi. Universitas Mercu Buana. Jakarta.

Safaryani, N., S. Haryanti, E.D. Hastuti. 2007. Pengaruh suhu dan lama penyimpanan terhadap penurunan kadar vitamin $\mathrm{c}$ brokoli (Brassica oleracea). Buletin Anatomi dan Fisiologi 15(2): 39-46.

Stewart, I., T.A. Wheaton. 1971. Effect of ethylene and temperature on carotenoid pigmentation of Citrus peel. Florida
Agricultural Experiment Station Journal. 4151: 264-266.

Sumiasih, I.H. 2011. Studi perubahan kualitas pascapanen buah manggis (Garcinia mangostana L.) pada beberapa stadia kematangan dan suhu simpan. Tesis. Institut Pertanian Bogor. Bogor.

Utama, I.M.S., Y. Setio, I.A.R.P. Puja, N.S Antara. 2011. Kajian atmosfir terkendali untuk memperlambat penurunan mutu buah mangga Arumanis selama penyimpanan. J. Hort. Indonesia. 2(1): 27-33. 